\title{
Voltinism of Aleurothrixus floccosus Maskel (Hemiptera: Aleyrodidae) in an oasis agroecosystem in the Atacama Desert, Tarapacá Region, Chile
}

\author{
Voltinismo de Aleurothrixus floccosus Maskel (Hemiptera: Aleyrodidae) en un \\ agroecosistema de oasis en el Desierto de Atacama, Región de Tarapacá, Chile
}

Víctor Tello ${ }^{*}$, Osman Peralta ${ }^{1}$ Tommy Rioja ${ }^{1}$

\begin{abstract}
The number of generations of woolly whitefly [Aleurpthrixus floccosus (Maskell)] was determined on sweet orange orchards [Citrus sinensis (L.) Osbeck] in the Pica Oasis, Tarapacá Region, Chile. The essays lasted one year, from April 2010 to April 2011. Woolly whitefly presented 7 generations in the Pica Oasis, which overlap causing the constant presence of this pest in Pica. In the coldest months (autumn-winter) the cycle tends to be longer (65.5 days), while in the warmer months (spring-summer) the cycle lasts 45.5 days. In general, the cycle is completed at 52 days.

Keywords: Generations, woolly whitefly, citrus, Pica.
\end{abstract}

\section{RESUMEN}

Se determinó el número de generaciones de la mosca blanca algodonosa de los cítricos [Aleurothrixus floccosus (Maskell)] en huertos de naranja dulce [Citrus sinensis (L.) Osbeck] en el Oasis de Pica, Región de Tarapacá, Chile. Los ensayos tuvieron una duración de un año, desde abril del 2010 hasta abril de 2011. La mosca blanca de los cítricos presentó 7 generaciones en el Oasis de Pica, cuyos estadios se superponen causando la presencia constante de esta plaga en Pica. En los meses más fríos (otoño-invierno) el ciclo tiende a ser más largo (65,5 días), mientras que en los meses más cálidos (primavera-verano) el ciclo dura 45,5 días. En general, el ciclo se completa a los 52 días.

Palabras claves: Generaciones, mosca blanca algodonosa de los cítricos, cítricos, Pica.

\section{Introduction}

The species Aleurothrixus floccosus (Maskell) 1895 , the citrus woolly whitefly, is a polyphagous species of South American origin. In Chile, infestations occur on varios broadleaved evergreen plants, including citrus fruits [lemon (Citrus limon (L.) B.), tangerine $(C$. reticulata $\mathrm{B}$.), orange (C. sinensis (L.) O.), pomelo ( $C$. grandis $\mathrm{H}$.). In recent years, it has also been recorded on lucuma [Pouteria lucuma (Ruiz \& Pav.) Kuntze] and guava (Psidium guajava L.) (Klein and Waterhouse, 2000; Rojas, 2005; Luppichini et al., 2008). Its distribution, in Chile, comprise from the Region of Arica and Parinacota to the Region of Bío-Bío, absent in the Region of Antofagasta (Klein y Waterhouse, 2000). In Chile, their host plants are orange, mandarin, lemon, grapefruit and lime. In recent years, it has also been recorded on lucuma and guava (Klein and Waterhouse, 2000; Rojas, 2005; Luppichini et al., 2008). The body and two pairs of membranous wings of adult females and males of these insects are covered with a white waxy substance. The adult female is about $1.5 \mathrm{~mm}$ in length with the male slightly smaller. The eggs give rise to nymphs, which, after walking a short distance, insert

\footnotetext{
1 Facultad de Recursos Naturales Renovables, Universidad Arturo Prat, Avenida Arturo Prat 2120, Casilla 121, Iquique, Chile.

* Autor por correspondencia: vtello@unap.cl
} 
their stylets into the mesophyll tissue of leaves. During their development they pass through four nymphal stages, during which thin waxy filaments are secreted that gradu- ally cover the body. Whitefly prefer to feed and oviposit on the undersides of young leaves that sprout when their host trees are actively growing (Ripa et al., 1999; Giliomee \& Millar, 2009). The citriculture of the Pica Oasis (Tarapacá Region, Chile) is strongly attacked by this aleyrodid, which is present throughout the year, overlapping its life stages, but the number of generations in the agroclimatological conditions of this oasis is unknown. The aim of this study was to determine the number of generations of A. floccosus in oasis conditions in the desert of northern Chile.

\section{Materials and Methods}

The experiments were carried out in sweet orange orchard [Citrus sinensis (L.) Osbeck] (Liceo Padre Hurtado, Pica, Región de Tarapacá, Chile) (20²9’S, $69^{\circ} 19^{\prime} \mathrm{W}$; 1,348 m.a.s.1.). For these assays, muslin sleeves were used for the purpose of protection and to prevent escape and reinfestation of adults of $A$. floccosus. A branch with new leaves and that was clean of pests was chosen, which was covered by the sleeve. Subsequently, approximately 100 adults of A. floccosus were left in the sleeve in order to observe oviposition.

When the first colonies of nymphs were obtained, the infested branches were agitated, to eliminate all the adults. This branch that contained only nymphs was reviewed frequently until they reached adulthood. The 100 adults who first emerged were transferred to a new uninfested branch (covered with a muslin sleeve). These insects were considered as representative adults of the next generation. Finally, emergency data of adults by generation were be recorded, repeating the procedure for one year.

\section{Results and Discussion}

The essays lasted one year, from April 2010 to April 2011. The average temperature between April 2010 and April 2011 was $19.58 \pm 0.62^{\circ} \mathrm{C}$, varying between a minimum average of $14.69^{\circ} \mathrm{C}$ and an average maximum of $22.32^{\circ} \mathrm{C}$. Under these temperature conditions, A. floccosus presented 7 generations in the Pica Oasis, which overlap causing the constant presence of this pest in Pica (Table 1 and Figure 1).

Table 1. Average time for the development of each generation of Aleurothrixus floccosus in the conditions of the Pica Oasis, Tarapacá Region of Chile, between April 2010 and April 2011.

\begin{tabular}{lc}
\hline Generation & Time from egg to adult (days) \\
\hline First & 66 \\
Second & 65 \\
Third & 45 \\
Quarter & 50 \\
Fifth & 43 \\
Sixth & 44 \\
Seventh & 48 \\
Promedio & 52 \\
\hline
\end{tabular}

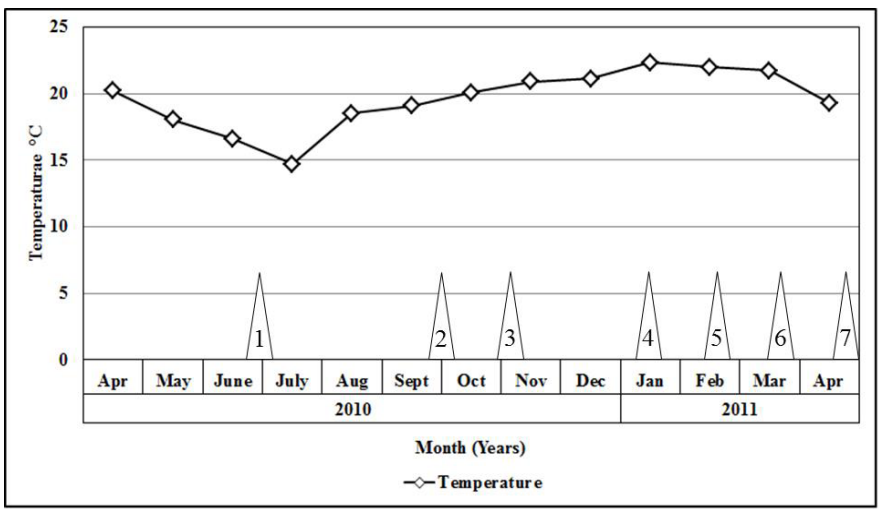

Figure 1. Population peaks of alate Aleurothrixus floccosus (triangles) and temperature recorded from April 2010 to April 2011 in the Oasis of Pica. 
In the coldest months (autumn-winter) the cycle tends to be longer (65.5 days), while in the warmer months (spring-summer) the cycle lasts 45.5 days. In general, the cycle is completed at 52 days. The results obtained in this study are similar to those registered by Onillon and Abbassi (1973), Pérez et al. (1973), Watts y Alam (1973), Vulic and Beltrán (1977), Carrero and Tarancón (1979), Ortu and Ibba (1985), Paulson and Beardsley (1986), Onillon (1990), Byrne and Bellows (1991), and Alford (2017) who point out that A. floccosus can present more than two and up to eight generations per year. According to Ripa and Larral (2008), in Chile the woolly whitefly is an insect that has more than two generations during the year, depending on the climatic conditions. The tests carried out in lemon trees in the province of Quillota, show that the cycle of this pest in the field, takes approximately 60 days in spring and 50 days in summer, from the state of the egg to the emergence of the adult. In addition, the authors indicate that from the Region of Arica and Parinacota to the Atacama Region there is a continuous reproduction of the woolly whitefly throughout the year.

In Peru, the woolly whitefly presents three generations in the year, completing its development from egg to adult in 48 days under summer conditions $\left(30^{\circ} \mathrm{C}\right.$ and $\left.70 \% \mathrm{RH}\right)$ (Núñez, 1995).

\section{Conclusions}

In the Oasis of Pica, the woolly whitefly is present throughout the year, overlapping its different states. The prevailing climatic conditions in this oasis allow A. floccosus to find the favorable conditions of habitat and environmental offer (food) to remain active in all seasons.

\section{Literature cited}

Alford, D.V.

2017. Pests of Fruit Crops: A Colour Handbook, Second Edition. CRC Press. 462 p.

Byrne, D.; Bellows, T.

1991. Whitefly Biology. Annu. Rev. Entomol. 36: 431-457.

Carrero, J.M.; Tarancón, J.

1979. Contribución al estudio de la biología de la mosca blanca de los agrios, Aleurothrixus floccosus Mask., en la región valenciana. II. Datos biológicos de campo, 1974. An. INIA. Ser. Prot. Veg., 9: 93-105.

Klein, C.; Waterhouse, D.F.

2000. The distribution and importance of arthropods associated with agriculture and forestry in Chile (Distribución e importancia de los artrópodos asociados a la agricultura y silvicultura en Chile). ACIAR Monograph No. 68. 234p.

Onillon, J.

1990. The use of natural enemies for the biological control of witheflies.Pp.: 287-313 in Whiteflies: their Bionomics Pest Status and Management. Dan Gerling (Ed.) Intercept Ltd., Andover, Hants, U.K., 348 p.

Onillon, J.; Abbassi, M.

1973: Notes bio-ecologiques sur l'aleurode flocconeux des agrumes Aleurothrixus floccosus Mask. (Homop., Aleurodidae) et moyens de lutte. Al-Awamia, 49: 99-116.
Ortu, S.; Ibba, I.

1985. Aleurothrixus floccosus (Mask.) in Sardinia. Atti XVI Congr. Naz. Ital. Di Entomol., Accadem. Naz. Italian. Di Entomologia (1985). pp 607-614.

Paulson, G. S.; Beardsley, I. W. 1986. Development, oviposition and longevity of Aleurothrixus jloccosus (Maskell) (Homoptera: Aleyrodidae). Proc. Hawaii. Entomol. Soc., 26:97-99.

Pérez-Ibañez, T.; Alberti-Maurici, J.; Calderon-Forns, E.;

Martiniex-Canales Murcia, G.; Vinaches Gomis, P. 1973. Generaciones anuales de Aleurothrixus howardi Quant. Mosca blanca de los agrios. Bol. Inf. Plagas, 109: 17- 19.

Vulic, M.; Beltrán, J.

1977. Die weibe fliege Aleurothrixu floccosus, ein gefahrlicher Schadling der Citruskulturen. Zeitschrift fur Pflanzenkrankheiten und Pflanzenschutz., 84:202-214.

Watts, W.S.; Alam, M .

1973. Spray trials against the citrus blackfly (Aleurocanthus woglumi) on limes in the Oman .Misc. Rep. Overseas Dev. Admin. For. Commonwealth Off. 8.7 p. 
